www.jmscr.igmpublication.org

Impact Factor 5.244

Index Copernicus Value: 83.27

ISSN (e)-2347-176x ISSN (p) 2455-0450

crossref DOI: _http://dx.doi.org/10.18535/jmscr/v4i10.15

Journal Of Medical Science And Clinical Research

\title{
Immediate Effects of M2T Blade on Pain and Range of Motion Inrecreational Badminton Shoulder Pain Subjects: A Pilot Study
}

\author{
Authors \\ Dr Varun Naik', Rozina Shaikh², Sadhvi Koyande ${ }^{3}$ \\ MPT, Lecture, KLE University Institute of Physiotherapy, Belagavi, India \\ KLE University Institute of Physiotherapy, Belagavi
}

\begin{abstract}
Background: shoulder pain is one amongst the common joint pain in recreational players. The shoulder pain hampers most of the activities of daily living due to restriction of range of motion at the joint and pain. Physiotherapy helps in relieving the pain by using various techniques and modalities. M2T is a myofascial release technique which helps in mobilization of the adherent fascia hence relieving pain and improving range of motion.

Patients and Methods: 7 recreational shoulder pain subjects between the age group 18-30 years were assesed from the KLE University's Indoor Stadium, Jawaharlal Nehru Medical College, Nehru Nagar, Belagavi, Karnataka.

Methods: Participants were assesed and treated with the M2T blade. Outcome measures used was the Visual Analog Scale (VAS) for pain and range of motion (ROM) was assesed by using a universal goniometer. The VAS and ROM was recorded pre and post intervention

Result: The VAS scores pre and post intervention is *p<0.05. The ROM score for shoulder flexion and extension is $* p<0.05$.

Conclusion: M2T blade is effective in immediately reducing pain and increasing range of motion in recreational shoulder pain subjects.

Key Words: M2T, Myofascial release, shoulder pain, Visual Analog Scale, Shoulder Range of Motion (ROM).
\end{abstract}

\section{INTRODUCTION}

Shoulder pain is a common musculoskeletal problem that affects people's daily activities it often does not have a specific diagnosis and is better described as symptoms that may have caused because of various pathologies ${ }^{1}$.Shoulder is a ball and socket joint were the humerus sits in the glenoid fossa. There is a capsule that attaches the glenohumeral joint to the scapula, humerus and head of biceps. Rotator cuff is a group of muscle and tendon that surround the shoulder joint and provides movements like abduction internal rotation and external rotation at the shoulder joint. Badminton is a sport that requires alot of overhead activities including shoulder abduction and external rotation. Previous shoulder pain was reported by $37 \%$ of the players and ongoing shoulder pain by $20 \%$ of the players, there were no significant differences in the prevalence of shoulder pain between men and women. ${ }^{2}$ In mechanical terms the shoulder has to deliver highly repetitive arm actions, performed at high speed and high force. This is also combined with 
reaching for the shuttle which may place the arm, shoulder girdle and trunk at extreme ranges of movement which may place the shoulder at increased risk of injury. ${ }^{8}$

M2T is a latest invention which helps us to release myofascial pain using the M2T blade. (fig1)

M2T blade was first invented in Canada by $\mathrm{Mr}$ Adam Boger and was used to reduced pain and increases the range of motion of the particular joint A method of designing highlyloaded blades to give a specified distribution of swirl is presented. The method is based on a newly developed, three-dimensional analysis. ${ }^{3}$

The blade consists of 8 treatment plane and areusing treatment plane number7 for this study

There are many studies that have been done on shoulder joint and reduction in the pain at shoulder joint but however, there are no evidences which suggest effectiveness of M2T blade in shoulder pain.

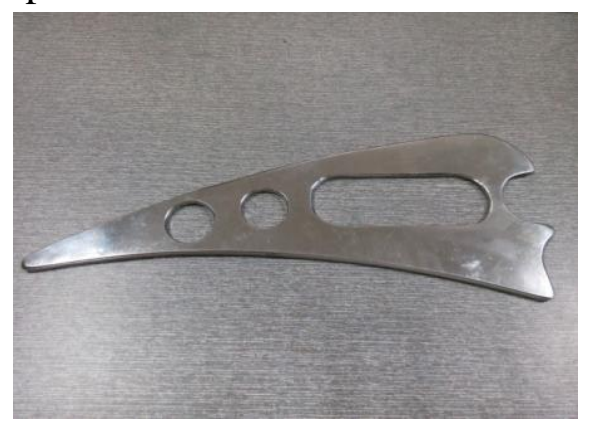

Figure:1

\section{METHOD}

Participants- 7 recreational badminton players

\section{Inclusion Criteria}

1. Recreational badminton players

2. Age group 18-30

3. Shoulder pain without any trauma or pathological conditions.

4. Subjects willing to participate

\section{Exclusion Criteria}

1. Any neurological deficits

2. Hypersensitive skin

3. Trauma to the shoulder joint in past 6 months

The study was carried out at KLE University's Indoor Stadium, Jawaharlal Nehru Medical College, Belagavi.

\section{OUTCOME MEASURES}

The outcome measures used were the Visual Analog Scale (VAS) to evaluate the pain in recreational badminton players and shoulder range of motion (ROM) using the universal goniometer. The pain was assessed by asking the subjects to mark number on a scale between $0-10$ were 0 symbolises no pain and 10 symbolises maximum pain.

The shoulder range of motion was assessed pre and post intervention using a universal goniometer.

\section{OBJECTIVES}

The primary objective of this study is to evaluate the immediate effects of myofascial release using the M2T blade on recreational badminton subjects with shoulder pain

The secondary objective of the study is to evaluate the difference in range of motion and pain post treatment

We would hypothesized that using the M2T blade would release the myofascial tightness around the shoulder joint, reduce the pain and increase the range of motion at the shoulder joint

\section{RESULTS}

Table 1: Sex wise distribution

\begin{tabular}{|l|l|l|l|}
\hline Sex & Number & Mean age & SD age \\
\hline Male & 4 & 19.75 & 1.50 \\
\hline Female & 3 & 19.67 & 1.15 \\
\hline Total & 7 & 19.71 & 1.25 \\
\hline
\end{tabular}

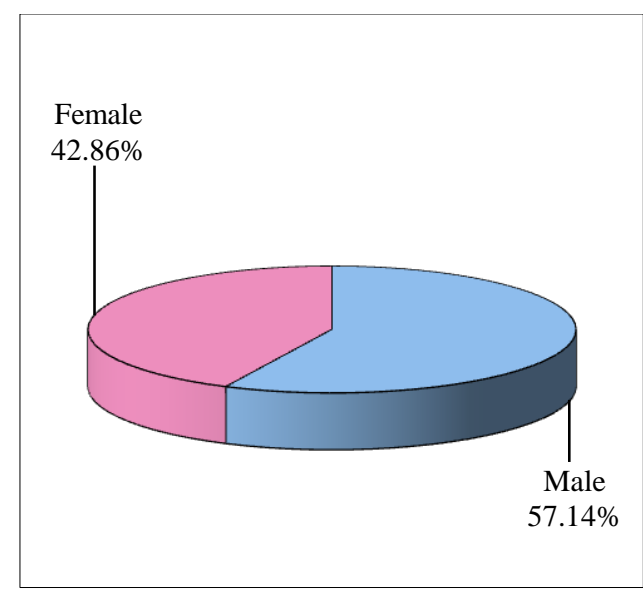

Figure 2: Sex wise distribution 


\section{JMSCR Vol||04||Issue||10||Page 12965-12968||October}

Table 2: Comparison of pre intervention and post intervention flexion scores by Wilcoxon matched pairs test

\begin{tabular}{|c|c|c|c|c|c|c|c|c|}
\hline $\begin{array}{l}\text { Intervent } \\
\text { ion }\end{array}$ & $\begin{array}{l}\mathrm{Me} \\
\text { an }\end{array}$ & $\begin{array}{l}\text { Std } \\
\text {.Dv } \\
\text {. }\end{array}$ & $\begin{array}{l}\text { M } \\
\text { edi } \\
\text { an }\end{array}$ & $\begin{array}{l}\text { Me } \\
\text { an } \\
\text { Diff } \\
\text {. }\end{array}$ & $\begin{array}{l}\text { SD } \\
\text { Dif } \\
\text { f. }\end{array}$ & $\begin{array}{l}\% \\
\text { of } \\
\text { cha } \\
\text { nge }\end{array}$ & $\begin{array}{l}\text { Z- } \\
\text { val } \\
\text { ue }\end{array}$ & $\begin{array}{l}\text { p- } \\
\text { val } \\
\text { ue }\end{array}$ \\
\hline $\begin{array}{l}\text { Pre } \\
\text { intervent } \\
\text { ion }\end{array}$ & $\begin{array}{l}149 \\
.29\end{array}$ & $\begin{array}{l}12 . \\
39\end{array}$ & $\begin{array}{l}15 \\
5.0 \\
0 \\
\end{array}$ & & & & & \\
\hline $\begin{array}{l}\text { Post } \\
\text { intervent } \\
\text { ion }\end{array}$ & $\begin{array}{l}173 \\
.86\end{array}$ & $\begin{array}{l}7.3 \\
6\end{array}$ & $\begin{array}{l}17 \\
5.0 \\
0 \\
\end{array}$ & $\begin{array}{l}- \\
24 . \\
57\end{array}$ & $\begin{array}{l}6.9 \\
2\end{array}$ & $\begin{array}{l}- \\
16 . \\
46\end{array}$ & $\begin{array}{l}2.3 \\
662\end{array}$ & $\begin{array}{l}0.0 \\
183 \\
* \\
\end{array}$ \\
\hline
\end{tabular}

$* \mathrm{p}<0.05$

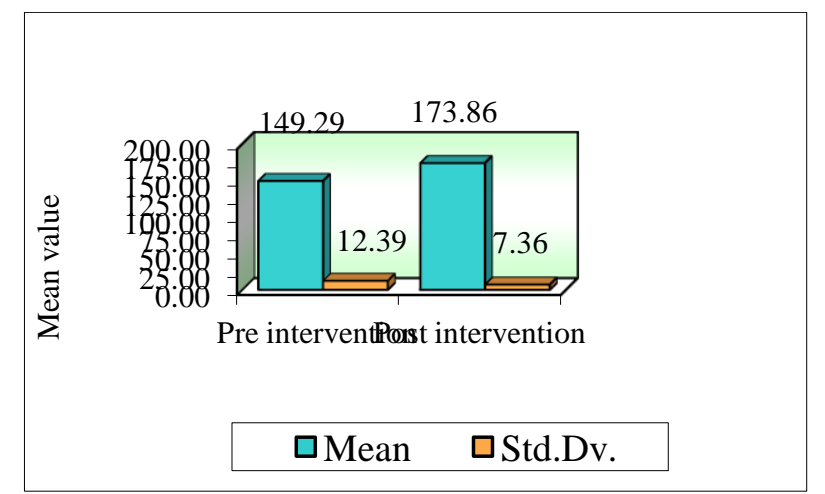

Figure 3: Comparison of pre intervention and post intervention flexion scores

Table 3: Comparison of pre intervention and post intervention extension scores by Wilcoxon matched pairs test

\begin{tabular}{|c|c|c|c|c|c|c|c|c|}
\hline $\begin{array}{l}\text { Interventio } \\
\mathrm{n}\end{array}$ & $\begin{array}{l}\mathrm{Me} \\
\text { an }\end{array}$ & $\begin{array}{l}\text { Std } \\
\text {.Dv } \\
\text {. }\end{array}$ & $\begin{array}{l}\mathrm{Me} \\
\text { dia } \\
\mathrm{n}\end{array}$ & $\begin{array}{l}\mathrm{Me} \\
\text { an } \\
\text { Dif } \\
\text { f. }\end{array}$ & $\begin{array}{l}\text { SD } \\
\text { Dif } \\
\text { f. }\end{array}$ & $\begin{array}{l}\% \\
\text { of } \\
\text { cha } \\
\text { nge }\end{array}$ & $\begin{array}{l}\text { Z- } \\
\text { val } \\
\text { ue }\end{array}$ & \begin{tabular}{|l}
$\mathrm{p}-$ \\
val \\
ue
\end{tabular} \\
\hline $\begin{array}{l}\text { Pre } \\
\text { intervention }\end{array}$ & $\begin{array}{l}37 . \\
86\end{array}$ & $\begin{array}{l}8.0 \\
7 \\
\end{array}$ & $\begin{array}{l}40 . \\
00\end{array}$ & & & & & \\
\hline $\begin{array}{l}\text { Post } \\
\text { intervention }\end{array}$ & $\begin{array}{l}54 . \\
86\end{array}$ & $\begin{array}{l}5.5 \\
5\end{array}$ & $\begin{array}{l}56 . \\
00\end{array}$ & $\begin{array}{l}- \\
17 . \\
00\end{array}$ & $\begin{array}{l}3.0 \\
6\end{array}$ & $\begin{array}{l}- \\
44 . \\
91\end{array}$ & $\begin{array}{l}2.3 \\
664\end{array}$ & $\begin{array}{l}0.0 \\
180 \\
*\end{array}$ \\
\hline
\end{tabular}

$* \mathrm{p}<0.05$

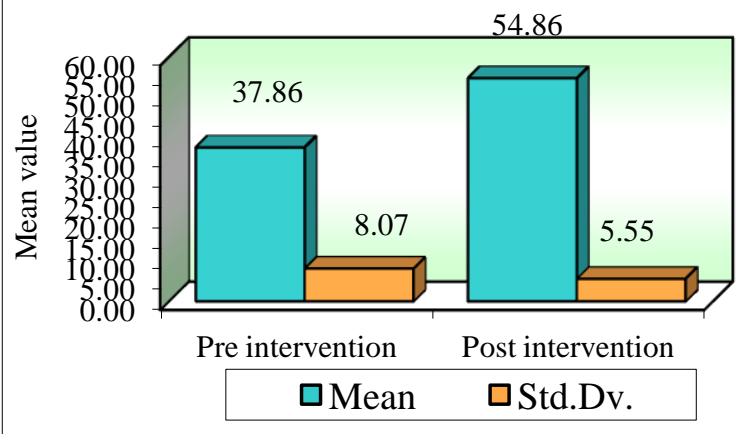

Figure 4: Comparison of pre intervention and post intervention extension scores
Table 4: Comparison of pre intervention and post intervention VAS scores by Wilcoxon matched pairs test

\begin{tabular}{|c|c|c|c|c|c|c|c|c|}
\hline $\begin{array}{l}\text { Interven } \\
\text { tion }\end{array}$ & $\begin{array}{l}\text { Me } \\
\text { an }\end{array}$ & $\begin{array}{l}\text { Std } \\
\text {.Dv } \\
.\end{array}$ & $\begin{array}{l}\mathrm{Me} \\
\text { dia } \\
\mathrm{n}\end{array}$ & $\begin{array}{l}\text { Me } \\
\text { an } \\
\text { Dif } \\
\text { f. }\end{array}$ & $\begin{array}{l}\text { SD } \\
\text { Dif } \\
\text { f. }\end{array}$ & $\begin{array}{l}\% \\
\text { of } \\
\text { cha } \\
\text { nge }\end{array}$ & $\begin{array}{l}\text { Z- } \\
\text { val } \\
\text { ue }\end{array}$ & $\begin{array}{l}p- \\
\text { val } \\
\text { ue }\end{array}$ \\
\hline $\begin{array}{l}\text { Pre } \\
\text { intervent } \\
\text { ion }\end{array}$ & $\begin{array}{l}6.0 \\
7\end{array}$ & $\begin{array}{l}1.2 \\
8\end{array}$ & $\begin{array}{l}6.1 \\
0\end{array}$ & & & & & \\
\hline $\begin{array}{l}\text { Post } \\
\text { intervent } \\
\text { ion }\end{array}$ & $\begin{array}{l}2.6 \\
1\end{array}$ & $\begin{array}{l}0.8 \\
3\end{array}$ & $\begin{array}{l}2.8 \\
0\end{array}$ & $\begin{array}{l}3.4 \\
6\end{array}$ & $\begin{array}{l}0.5 \\
9\end{array}$ & $\begin{array}{l}56 . \\
94\end{array}$ & $\begin{array}{l}2.3 \\
645\end{array}$ & $\begin{array}{l}0.0 \\
170 \\
*\end{array}$ \\
\hline
\end{tabular}

$* p<0.05$

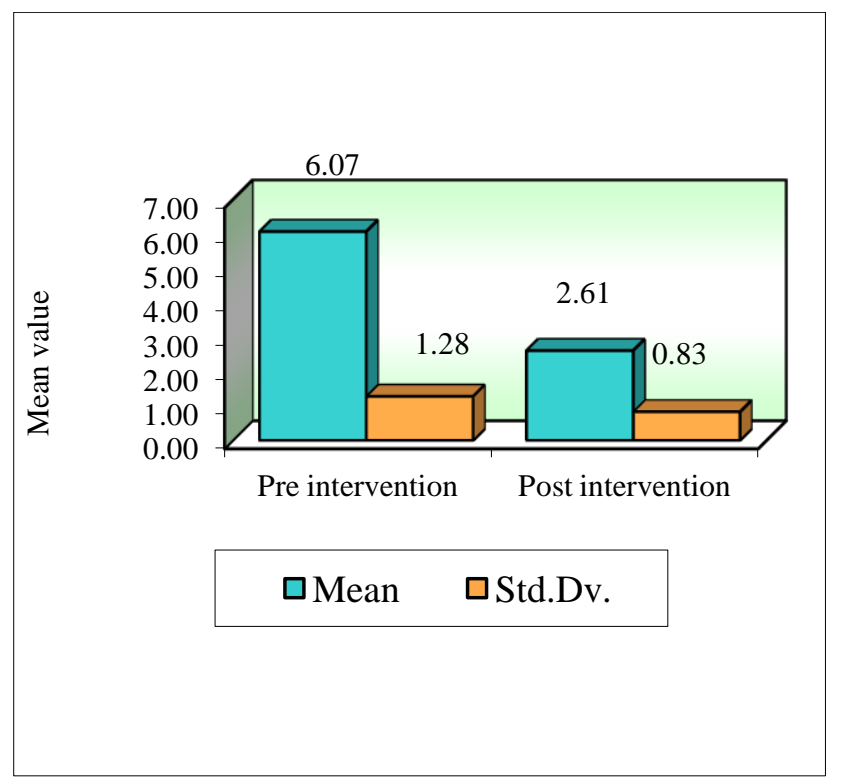

Figure 5: Comparison of pre intervention and post intervention VAS scores

\section{DISCUSSION}

The present study provides positive results in pain and range of motion in recreational shoulder pain subjects.To our best knowledge this is the first time a clinical trial has been performed to check the immediate effect of M2T blade to release fascial tightness.

In this study 7 recreational players with shoulder pain were taken.

Visual Analog Scale was used to measure the pain in the subject's pre- treatment and post treatment as VAS is more reliable for pain evaluation according to Bijur PE et al.

In study by Richard L Gajdasik and Richard W Bohannon, range of motion using universal goniometer was done. The study concluded that 
the universal goniometer has a good reliability and clinical utility according to Perdoma $\mathrm{M}$ et al.

The probable improvement in the outcome measures is ensured with enhanced length of fascia which is in consensus with previous study ${ }^{4}$ which showed simiar results by the use of MFR Technique.

M2T Blade works on the principle of Myofascial Release.

As in myofascial release there is a stretch applied on the tight fascia which is maintained for $90-120$ seconds proves to lengthen the tight fascia ${ }^{4}$. Similarly M2T blade also causes a stretch of the tight fascia till the adhesion were broken leading to release of fascia

As seen in the myofascial release technique repetitive stretch on the tight fascia softens $\mathrm{it}^{4}$. Similar effect is seen in this study as we use the blade on the tight fascia till the adhesions are broken and the fascia softens.

After the myofascial release the length of the fascia is restored and the pressure over the pain sensitive areas(blood vessels and nerves) are relieved, this restores the alignment of the joint and increases the mobility ${ }^{4}$. Similarly in this study after the fascia tightness around the shoulder joint was reduced the pain sensitive structures (blood vessels and nerves) were alleviated and the length of the fascia was restored, this reduced the pain and the range of motion at the shoulder joint increased.

Myofascial release causes controlled microtrauma and increases the number of fibroblasts which further promotes blood circulation ${ }^{7}$. In this study the use of M2T blade causes petechiae which is controlled microtrauma to the tissue, thus increasing the blood flow to the area.

Thus this study proves that using M2T Blade on tight fascia reduces the fascia tightness, reduces pain and increases the range of motion.

\section{CONCLUSION}

M2T blade is effective in immediately reducing pain and increasing range of motion in recreational shoulder pain subjects.

\section{REFFERENCE}

1. NS728 Walker J (2014) Shoulder pain: pathogenesis, diagnosis and management. Nursing Standard 28, 22, 51-58. Date of submission: July 262013 date of acceptance: October 172013

2. Pubmed.gov Scand J Med Sci Sports 2006 June

3. Theory of Blade Design for Large Deflections: Part II-Annular Cascades C. S. Tan, W. R. Hawthorne, J. E. McCune and C. Wang

4. The basic science of myofascial release: morphologic changes in connective tissue M.F. Barnes. Journal of bodywork and movement therapies. July 1997

5. International Journal of Health Sciences \& Research Vol.2; Issue: 2; May 2012

6. John F. Barnes, Myofascial Release The ""Missing Link"" in Your Treatment, PT Today, 1995

7. Davidson et al. Med Sci Sports Exerc. 1997; Gehlsen et al. Med Sci Sports Exerc.1999

8. Singapore Med J 2009 Nov; 50(11):1095) 